\title{
Anterior Corpus Callosotomy Combined with Anterior'Temporal Resection with Amygdalohippocampectomy: Outcome in a Patient with Congenital Bilateral Perisylvian Syndrome
}

\author{
Anterior Korpus Kallozotominin Anterior Temporal Rezeksiyon ile \\ Amigdalohippokampektomi Birlikteliği: Bir Hastada Konjenital Bilateral \\ Perisilvian Sendrom Sonucu
}

Zhu JUNMING ${ }^{1}$, Zhao YUANYUAN ${ }^{2}$, Feng FANG ${ }^{1}$, Fu WEIMING ${ }^{1}$, Hays RYAN ${ }^{3}$, Zhang JIANMIN ${ }^{1}$, Feng $_{\text {LI }}^{2}$, Jin $\mathrm{XIAO}^{2}$, Chen $\mathrm{SHUDA}^{2}$

${ }^{1}$ The Second Affiliated Hospital, Zhejiang University College of Medicine, Department of Neurosurgery, Hangzhou, China

2Zhejiang Provincial People's Hospital, Department of Neurosurgery, Hangzhou, China

${ }^{3}$ UT Southwestern Medical Center, Department of Neurology and Neurotherapeutics, Dallas, USA

Corresponding Author: Chen SHUDA / E-mail: chenshuda@sina.cn

\begin{abstract}
Congenital bilateral perisylvian syndrome (CBPS) is characterized by epilepsy, cognitive deficits, pseudobulbar palsy and diplegia of the facial, pharyngeal and masticatory muscles. Epilepsy has been described in nearly $90 \%$ of affected patients. The epilepsy is usually severe and pharmacoresistant in about 55 percent of CBPS patients. Until now, only 12 cases of surgical treatment on CBPS have been reported; the surgical treatment is usually corpus callosotomy. In this paper, we describe a previously unreported combination of anterior corpus callosotomy plus anterior temporal lobectomy with amygdalohippocampectomy for a patient with CBPS, resulting in a satisfactory clinical outcome. Based on this case, we suggest that palliative focal resective surgery combined with anterior corpus callosotomy should be considered when a predominance of the epileptiform discharges suggests focal onset in patients with CBPS. Meanwhile, the clinical decision to adopt this combination surgery must be based on a thorough pre-surgical evaluation, and should take into account the clinical, radiological, and EEG features.

KEYWORDS: Congenital bilateral perisylvian syndrome (CBPS), Anterior corpus callosotomy, Anterior temporal resection, Epilepsy, Amygdalohippocampectomy

öz

Konjenital bilateral perisylvian sendrom (KBPS) fasial, faringeal ve mastikasyon kaslarında epilepsi, kognitif defisitler, psödobulber palsi ve dipleji ile karakterizedir. Etkilenen hastaların neredeyse \%90'ında epilepsi tanımlanmıştır. KBPS hastalarının \%55'inde epilepsi şiddetli ve ilaçlara dirençlidir. Bugüne kadar sadece 12 olguda KBPS cerrahi tedavisi tanımlanmıştır; cerrahi tedavi genellikle korpus kallozotomidir. Bu makalede, bir KBPS hastasında daha önce bildirilmemiş anterior korpus kallozotomi, artı anterior temporal lobektomi ve amigdalohipokampektomi kombinasyonu ve sonuçta tatminkar bir sonuç bildiriyoruz. Bu olgu temelinde KBPS hastalarında epileptiform deşarjların ön planda olması fokal başlangıç düşündürdüğünde anterior korpus kallozotomi ile kombine palyatif fokal rezeksiyon cerrahisi öneriyoruz. Bu arada bu kombinasyon cerrahisini kullanma konusunda klinik karar kapsamlı bir cerrahi öncesi değerlendirmeyi temel almalı ve klinik, radyolojik ve EEG özelliklerine göre verilmelidir.
\end{abstract}

ANAHTAR SÖZCÜKLER: Konjenital bilateral perisylvian sendrom (KBPS), Anterior korpus kallozotomi, Anterior temporal rezeksiyon, Epilepsi, Amigdalohippokampektomi

\section{INTRODUCTION}

Congenital bilateral perisylvian syndrome (CBPS) was originally described in identical twins by Graff-Radford et al. (1986) (4). CBPS is a described entity diagnosed on the bases of neuroimaging and speech abnormalities (Kuziecky et al., 1989; Palmini et al., 1991) $(6,8-10)$. .CPBS is characterized by epilepsy, cognitive deficits, pseudobulbar palsy and diplegia of the facial, pharyngeal and masticatory muscles. Epilepsy has been described in up to $87 \%$ of affected patients (8). Reported seizure types range from atypical absence, atonic, tonic, or tonic-clonic seizures; the motor convulsions are typically generalized rather than partial. Seizures in CBPS 
usually begin between four to twelve years of age. The epilepsy is usually severe and pharmacoresistant in about 55 percent of patients (8). The literature on surgical treatment on CBPS is reviewed herein. Until now, only 12 cases of surgical treatment on CBPS have been reported $(1,3,6,8)$; the surgical treatment is usually corpus callosotomy $(1,14)$. In this paper, we describe a previously unreported combination of anterior corpus callosotomy plus anterior temporal lobectomy with amygdalohippocampectomy for a patient with CBPS, resulting in a satisfactory clinical outcome.

\section{CASE REPORT}

This 16-year-old woman, the first child born to nonconsanguineous parents, attended our epilepsy clinic because of seizures of 2.5 years duration. She had no family history of neurological diseases and was the offspring of a reportedly normal pregnancy and delivery. She weighed 2.1 $\mathrm{kg}$ and had an occipito-frontal head circumference of $37 \mathrm{~cm}$ at birth. She developed febrile convulsions at 13 months of age. Her mother noted delays in her motor development, including not walking independently until 3.5 years of age. Swallowing difficulties, drooling, and occasional choking were noted since early childhood.

She also had severely delayed language development with reduced vocalization and no babbling. Her expressive speech was slow and effortful. Reading aloud was difficult, although comprehension and writing were normal. She required special education throughout school.

She developed seizures at age of thirteen. Many types of seizures were noted, which included daily absence seizures, simple partial seizures and complex partial seizures. Various antiepileptic drugs, including dilantin, carbamazepine, luminal, clonazepam and sodium tungstate dihydrate were used to control the seizures. At the time of presentation, she continued to have seizures despite a combination of sodium valproate, lamotrigine and levetiracetam.

Our evaluation included neuro-psychological assessment, neurologic examination, electrophysiologic testing and neuroimaging. She had low verbal and performance IQ levels and the estimated Global IQ was 56.

Neurological examination revealed her to be attentive and responsive. She had limited movement and protrusion of the tongue outside the mouth (Figure 1). She had dysarthria with a lack of oromotor coordination and difficulties with palatal and lingual movements. She had a hyperactive jaw jerk. The remainder of the cranial nerve functions, including eye movements and ophthalmoscopy, were normal. She also demonstrated slightly diffuse hyperreflexia and bilaterally decreased fine rapid alternating movements. Dysmorphic features were not observed.

Toxoplasma, rubella, cytomegalovirus and herpes virus (TORCH) screenings were negative. In addition, testing for myotonic dystrophy, urine and serum amino acids, urine organic acids, Watson-Schwartz test, serum ceruloplasmin, and urine heavy metals were negative. Chromosomal analysis was normal. Electrocardiogram, echocardiogram, and abdominal ultrasonography were normal.

\section{EEG}

Video EEG monitoring (10-20 System) demonstrated sharp waves in bi-temporal regions as well as independent left or

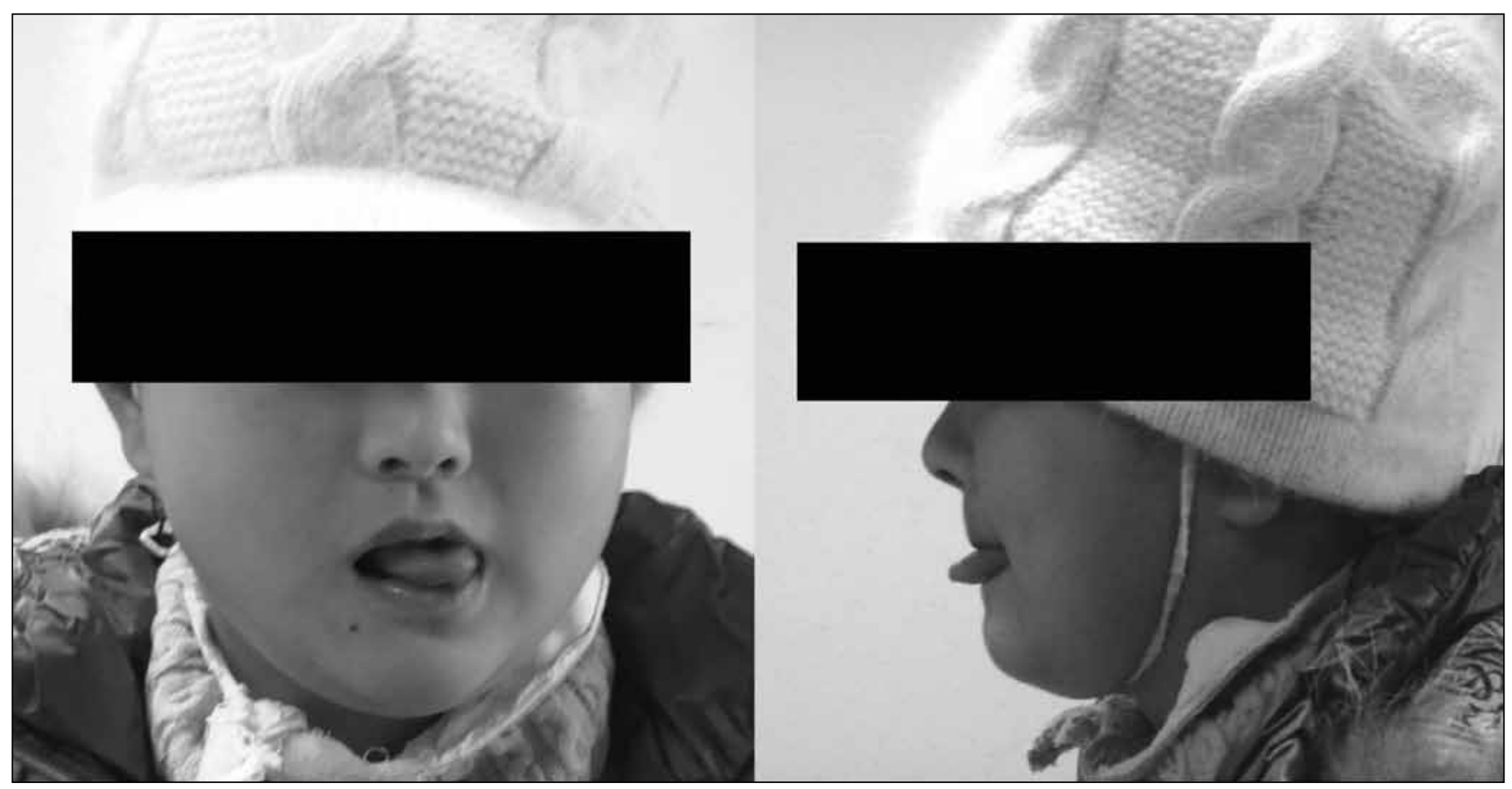

Figure 1: Limited movement and protrusion of the tongue outside the mouth. 
right temporal region. Eight clinical seizures were recorded with a stereotyped semiology consisting of dialeptic seizure with eye deviation, followed by mouth and hand automatism 40 seconds later. Electrographically, five of the clinical seizures were associated with onset of repetitive sharp waves in the left temporal region; while three of the seizures were associated with onset of repetitive sharp waves in the right temporal region. EEG seizures lasted for 3-4 minutes (Figure $3 A, B, D)$.

\section{CT}

CT demonstrated deep bilateral and symmetrical clefts in the region of the Sylvian fissures.

\section{MRI}

Brain magnetic resonance imaging (MRI) examination of the patient was performed on a 3.0 Tesla Siemens magnetic resonance (MR) imager. T1-weighted spin-echo (SE) (repetition time $(T R)=440 \mathrm{msec} /$ echo time $(T E)=15 \mathrm{msec}$ ), T2weighted fast spin-echo (FSE) ( $T R=4400 \mathrm{msec} / T E=100 \mathrm{msec}$ ), and fluid attenuated inversion recovery sequence (FLAIR) ( $T R=8800 \mathrm{msec} / \mathrm{TE}=140 \mathrm{msec}, \mathrm{Tl}=2200 \mathrm{msec}$ ) images in axial, coronal and sagittal planes were obtained. The slice thickness was $3 \mathrm{~mm}$. No gadolinium-based contrast material was administered. Bilateral symmetrical dysplastic cortices were observed in the region of the Sylvian fissures (Figure $2 A-C$ ). The sylvian fissures extended more superiorly and posteriorly than normal. The subarachnoid spaces were enlarged. Large cortical veins were present in the vicinity of the polymicrogyria. No nodular heterotopia or other abnormality was present.

Based on these findings, a diagnosis of CBPS was established.

Since the seizures were pharmacoresistant, the patient underwent anterior corpus callosotomy and left anterior temporal lobectomy with amygdalohippocampusection (since the majority of the patient's recorded seizures had onset from the left temporal region) at the age of 17 years. No post-operative complication was noticed.

In our standard anterior temporal lobe resection, the extent of the temporolateral resection is $4 \mathrm{~cm}$ along the superior and middle temporal gyrus and $5 \mathrm{~cm}$ along the inferior temporal gyrus. The hippocampus and the parahippocampal gyrus are usually resected en bloc, and the resection reaches the middle of the cerebral peduncle at its widest diameter.

One month after surgery, a 24-hour EEG demonstrated sporadic moderate amplitude spikes at a frequency of $3-5 \mathrm{~Hz}$ in the right temporal region (Figure $3 \mathrm{C}$ ).

At one year of follow-up, she remains free of seizures (Engle class I). Additionally, surgery resulted in improved behavior and social adaptation.

\section{DISCUSSION}

CBPS is related to bi-opercular cortical dysplasia, with the main clinical features being pseudobulbar palsy, mild mental retardation and epilepsy with multiple seizure types.

Epilepsy was found in nearly $90 \%$ of cases in the series reported by Kuzniecky, et al. (8). Seizures in CBPS usually begin between the ages of four to twelve years of age, and are refractory in about sixty percent of patients.

The treatment on CBPS mainly focuses on controlling seizures, which includes pharmacotherapy and surgery (14). In these patients, appropriate, but aggressive seizure treatment should be instituted for several reasons. First, frequent seizures may exacerbate speech dysfunction. Second, some patients have progressive cognitive deterioration, probably related to their epilepsy. Third, frequent seizures (particularly atonic and generalized tonic-clonic seizures) may increase the risk of physical injury or even sudden unexpected death

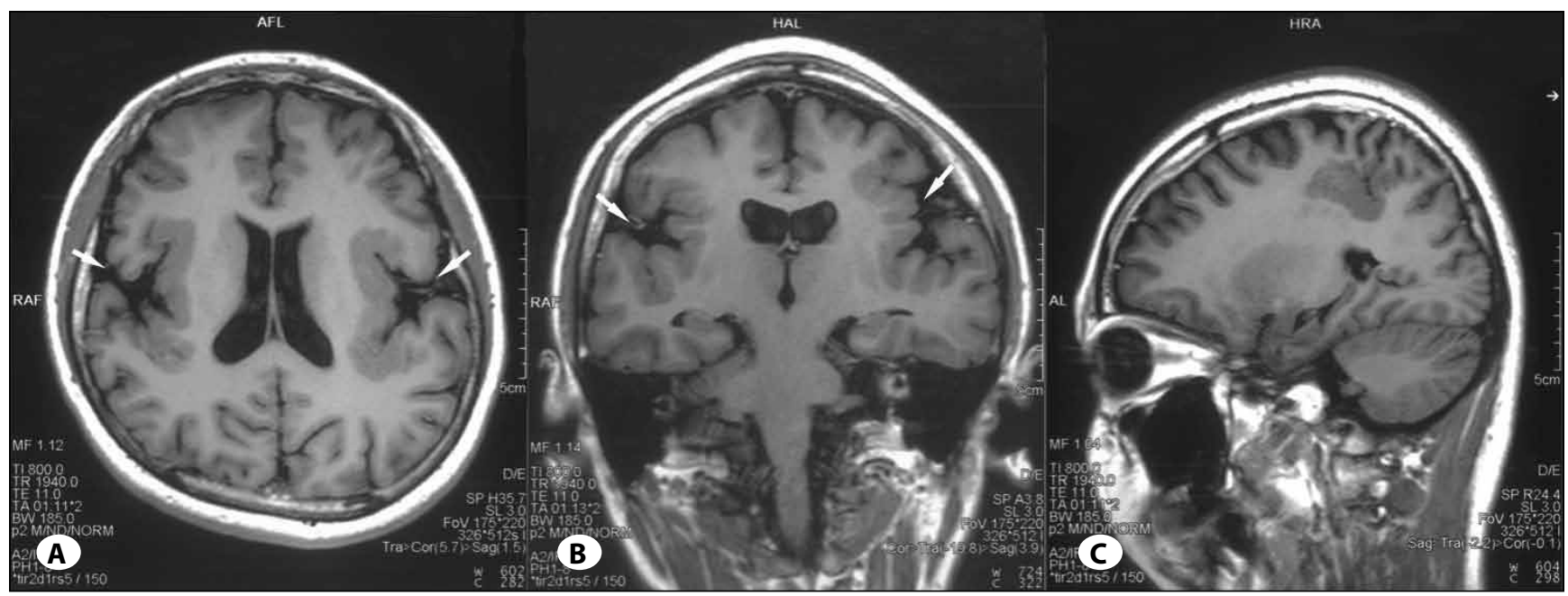

Figure 2: A, B) Axial and coronal T1-weighted MR scans demonstrate that the sylvian fissures are abnormally formed bilaterally (white arrows) and are lined by polymicrogyric cortex extending posteriorly into the parietal parasagittal area (arrowheads), C) Sagittal T1weighted image shows polymicrogyria of the perisylvian cortex, posteriorly extending into the parieto-occipital cortex. 


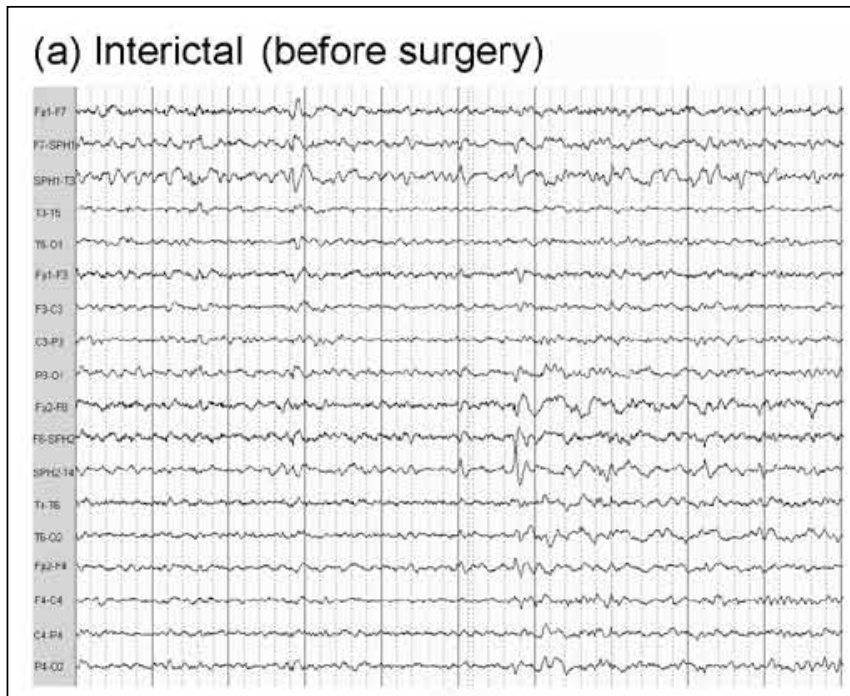

(b) Ictal 1 (before surgery)

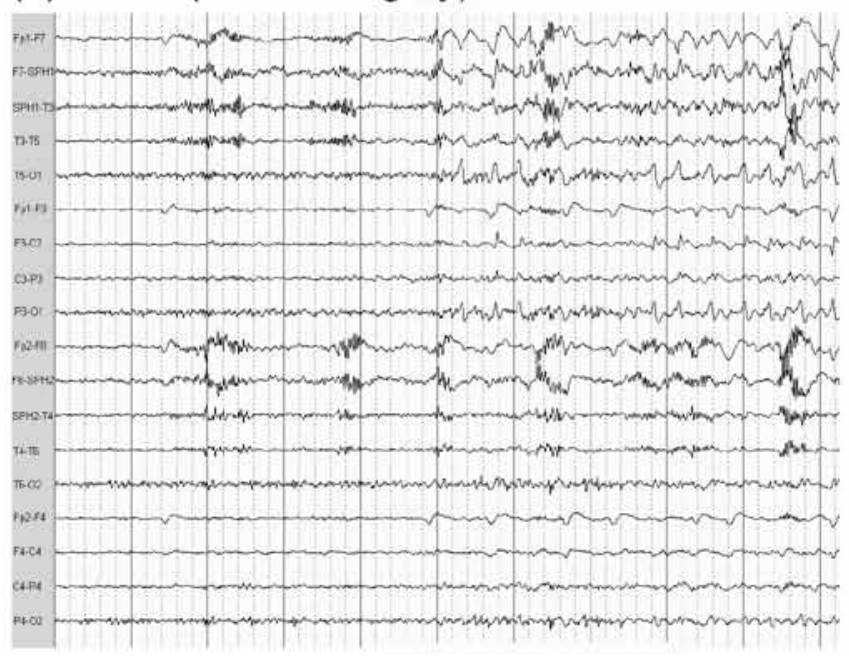

(c) Interictal (after surgery)

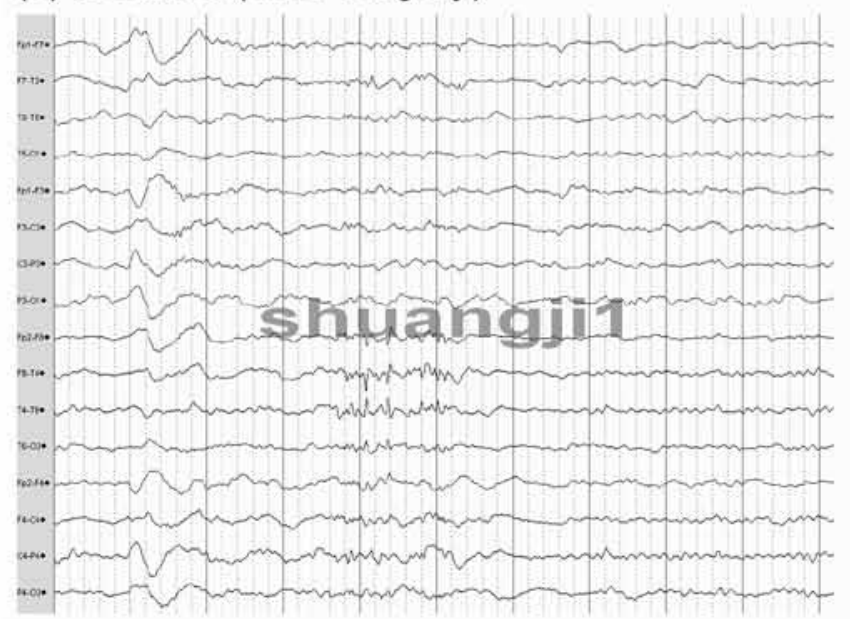

(d) Ictal 2 (before surgery)

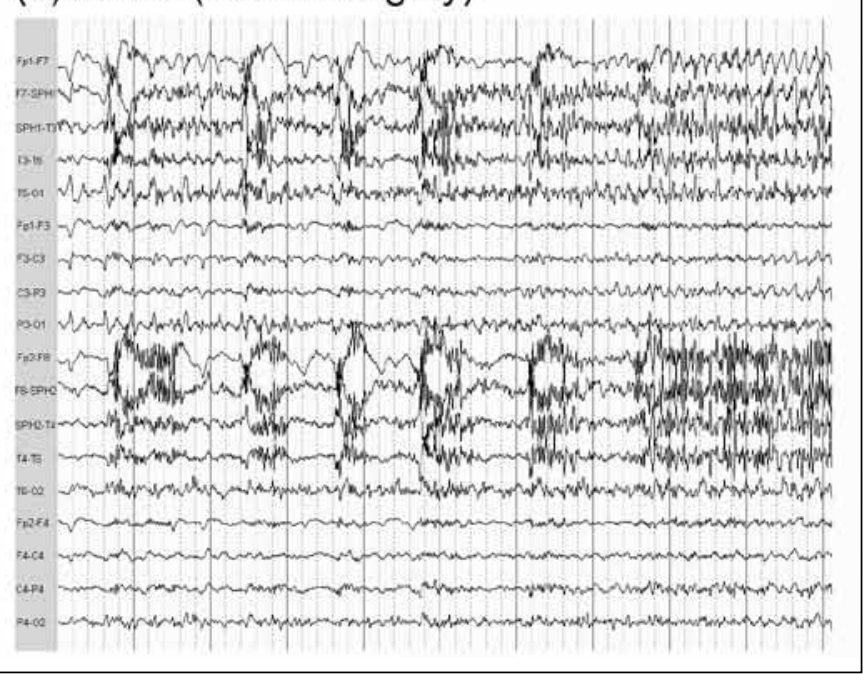

Figure 3: A) Frequent interictal sharp waves were seen in bilateral mesial temporal regions before surgery (maximum in SPH1 and SPH2). SPH1/SPH2, left/right sphenoidal electrode. B, D) Ictal pattern: onset of repetitive sharp waves in the left temporal region before surgery (maximum in T3/SPH1) which evolved into alpha rhythm 5 seconds later. C) One month after surgery, a 24-hour EEG demonstrated sporadic moderate amplitude spikes at a frequency of 3-5 Hz in the right temporal region.

in epilepsy (SUDEP). Therefore, a surgical evaluation should be considered early after the patient has demonstrated pharmacoresistance.

Around 170 CBPS cases have been reported in the literature $(2,3,5-13,15,16)$. Most cases of CBPS have been determined not to be candidates for focal resective surgery due to diffuse epileptiform discharges and bilateral structural lesions. Only twelve cases of surgery in this population have been reported, including corpus callosotomy for 10 cases and anterior temporal resection for 2 cases (Table I) $(1,3,6,8)$. Kuzniecky et al first described corpus callosotomy for seven patients with CBPS, with varying degrees of success (8). Kim et al reported anterior right temporal lobectomy with amygdalocampusection for a 19 year old CBPS patient with seizure freedom eight months post-operatively (6).
In our case, the patient presented with the classical clinical triad of CBPS, which included congenital facio-masticatory diplegia, epilepsy, and moderate mental retardation. EEG showed bitemporal onset multifocal abnormalities, but the majority of seizures appeared to have a left-temporal onset. Anterior corpus callosotomy was selected based on the intractability of these seizure disorder, coupled with a palliative anterior temporal lobectomy with amygdalohippocampectomy since the majority of the recorded seizures had onset from the left anterior temporal lobe. One year after surgery, the patient remained completely seizure free and she has demonstrated improved behavior and social adaptation.

In conclusion, aggressive surgical treatment should be considered for patients with CBPS and intractable epilepsy. Based on this case, we suggest that palliative focal resective 
Table I: Literature Summary of Surgical Cases with CBPS

\begin{tabular}{|c|c|c|c|c|}
\hline Literature & Cases & Operations & $\begin{array}{l}\text { Follow-up } \\
\text { time(months) }\end{array}$ & Outcome \\
\hline Kuzniecky et al. 1993 & 7 & $\begin{array}{l}4 \text { had anterior two-thirds } \\
\text { callosal sections } \\
2 \text { patients required extended callosal } \\
\text { sections } \\
1 \text { three-stage complete division of the } \\
\text { corpus callosum }\end{array}$ & $36(16-50)$ & $\begin{array}{l}\text { improved behavior } \\
\text { and } \\
\text { social adaptation }\end{array}$ \\
\hline Kim et al. 1994 & 1 & $\begin{array}{l}\text { anterior temporal resection with } \\
\text { amgdalohippocampectomy }\end{array}$ & 8 & complete seizure relief \\
\hline Ambrosetto and Antonini 1995 & 1 & two-thirds anterior callosotomy & 6 & $\begin{array}{l}\text { Improved, despite } \\
\text { complete resolution of } \\
\text { drop attacks }\end{array}$ \\
\hline Hongzhou Duan et al. 2008 & 1 & anterior temporal resection & 10 & better seizure control \\
\hline Yoshiaki et al. 2009 & 2 & total callosotomy & 24 & better seizure control \\
\hline
\end{tabular}

surgery combined with anterior corpus callosotomy should be considered when a predominance of the epileptiform discharges suggest focal onset in patients with CBPS. Obviously, the clinical decision to add such a focal resection to a standard callosotomy must be based on a through presurgical evaluation, and should take into account the clinical, radiological, and EEG features. Additionally, further research into the identification of which patients will most benefit from such a combined technique, as well as how to avoid surgical complications, is warranted.

\section{REFERENCES}

1. Ambrosetto G, Antonini L: Anterior corpus callosotomy: Effects in a patient with congenital bilateral perisylvian syndrome and oromotor seizures. J Neurol Sci 16:311-314, 1995

2. Clark M, Carr L, Reilly S, Neville BG: Worster-Drought syndrome, a mild tetraplegic perisylvian cerebral palsy. Review of 47 cases. Brain 123: 2160-2170, 2000

3. Duan H, Zhang JY, Bao SD: Congenital bilateral perisylvian syndrome: a case report. Beijing Da Xue Xue Bao 40:645-648, 2008

4. Graff-Radford NR, Bosch EP, Stears JC, Tranel D: Developmental Foix-Chavany-Marie syndrome in identical twins. Ann Neurol 20: 632-635, 1986

5. Herrera EP, Brandao-Almeida IL, Guimaraes CA, Oliveira EP, Montenegro MA, Cendes F, et al: Perisylvian syndrome: Report of one Brazilian family with focus on the genetic mode of inheritance and clinical spectrum. Arq Neuropsiquiatr 63:459-463, 2005

6. Kim HI, Palmini A, Choi HY, Kim YH, Lee JC: Congenital bilateral perisylvian syndrome: Analysis of the first four reported Korean patients. J Korean Med Sci 9:335-340, 1994
7. Kuker W, Friese S, Riethmuller J, Krageloh-Mann I: Congenital bilateral perisylvian syndrome (CBPS): Do concomitant esophageal malformations indicate a poor prognosis? Neuro Pediatrics 31:310-313, 2000

8. Kuzniecky R, Andermann F, Guerrini R: Congenital bilateral perisylvian syndrome: Study of 31 patients. The CBPS Multicenter Collaborative Study. Lancet 341:608-612, 1993

9. Kuzniecky R, Andermann F, Guerrini R: The epileptic spectrum in the congenital bilateral perisylvian syndrome. CBPS Multicenter Collaborative Study. Neurology 44: 379-385, 1994

10. Kuzniecky R, Andermann F, Guerrini R: Infantile spasms: An early epileptic manifestation in some patients with the congenital bilateral perisylvian syndrome. J Child Neurol 9: 420-423, 1994

11. Lenti C, Triulzi F: Discordant clinical and neuroradiological features of congenital bilateral perisylvian syndrome in monozygotic female twins. Ital J Neurol Sci 17: 287-290, 1996

12. Luat AF, Bernardi B, Chugani HT: Congenital perisylvian syndrome: MRI and glucose PET correlations. Pediatr Neurol 35: 21-29, 2006

13. Nevo Y, Segev Y, Gelman Y, Rieder-Grosswasser I, Harel S: Worster-Drought and congenital perisylvian syndromes-a continuum? Pediatr Neurol 24:153-155, 2001

14. Saito Y, Sugai K, Nakagawa E, Sakuma H, Komaki H, Sasaki M, et al: Treatment of epilepsy in severely disabled children with bilateral brain malformations. J Neurol Sci 277: 37-49, 2009

15. Sejima H, Takusa Y, Kimura M, Tamaoki Y, Kishi K, Yamaguchi $S: A$ variant case of congenital bilateral perisylvian syndrome with asymmetric findings on neuroimaging and septum pellucidum defect. Brain Dev 23: 131-134, 2001

16. Tagawa T, Itagaki Y, Kobayashi M, Sano T, Sumi K: Nonconvulsive status epilepticus in a child with congenital bilateral perisylvian syndrome. Pediatr Neurol 21: 579-582, 1999 